\title{
Mystery Case: A 78-year-old man with a gait disorder
}

Miguel Saucedo, MD, Anibal Chertcoff, MD, Lucrecia Bandeo, MD, Luciana León Cejas, MD, Claudia Uribe Roca, MD, Pablo Bonardo, MD, Manuel Fernandez Pardal, MD, Rafael Torino, MD, Julian Mendez, MD, and Ricardo Reisin, MD

Neurology ${ }^{\circledR}$ 2019;93:223-227. doi:10.1212/WNL.0000000000007865

\section{Section 1}

A 78-year-old right-handed man was admitted to our department with a gait disorder that had begun 45 days ago. He had a history of alcohol and tobacco use, moderate chronic obstructive pulmonary disease, follicular non-Hodgkin lymphoma without treatment, lung adenocarcinoma in complete remission, and psoriasis. His gait disorder had evolved progressively. At first, he had difficulty climbing stairs due to weakness of his lower limbs accompanied by severe lower back pain without irradiation or antalgic posture. Then, he developed multiple falls from a standing position. Finally, he started complaining of urinary urgency, which began 2 weeks before he was hospitalized. On examination, cognitive functions, evaluated by Mini-Mental State Examination, and cranial nerves were normal. He presented with a flaccid paraparesis (iliopsoas: R: 4/5, L: 3/5; quadriceps: R: 4-/5, L: 4-/5; hamstrings: R: 4/5, L: 4/5); deep tendon reflexes were normal in the upper limbs but decreased in lower limbs. Plantar reflexes were absent and superficial abdominal cutaneous reflexes were abolished. He had neither clonus nor Hoffman sign. He had reduced pinprick, light touch, vibration, and position sense in both legs with a T10 sensory level and ataxic gait. He had no spasticity.

\section{Questions for consideration:}

1. Where do you think the lesion that is affecting this patient is located?

2. What additional diagnostic tests would you consider performing?
Correspondence

Dr. Saucedo

mas.ing@hotmail.com

MORE ONLINE

Survey and results

NPub.org/mc9305

GO TO SECTION 2

From the Departments of Neurology (M.S., A.C., L.B., L.L.C., C.U.R., P.B, M.F.P., R.R.), Neurosurgery (R.T.), and Pathology (J.M.), Hospital Británico de Buenos Aires, Argentina.

Go to Neurology.org/N for full disclosures. Funding information and disclosures deemed relevant by the authors, if any, are provided at the end of the article. 


\section{Section 2}

Weakness of the lower limbs could be due to injury of the spinal cord, the spinal nerve roots, the peripheral nerves, or secondary to muscle involvement. Considering the presence of a sensory level, the involvement of both deep and superficial sensation, the presence of urinary urgency, and ataxic gait probably secondary to damage in the dorsal and ventral spinocerebellar pathways, the clinical scenario could point towards involvement of the spinal cord. Nevertheless, our patient had also presented with signs of peripheral nerve involvement such as decreased reflexes in lower limb, sensory complaints, and a lack of pyramidal signs. Pain in the lower back could be due to involvement of osteoarticular structures, sensory dorsal roots, or meninges. The clinical clues enabling us to provide an approximate location of the lesion are the motor involvement restricted to the lower limbs, the absence of abdominal skin reflexes, and the sensory level located on T10. An MRI of the thoracic-lumbar spine and a CT of the thoracic-lumbar spine were performed: a nodular lesion within the spinal cord with strong contrast enhancement was observed both in MRI and CT (figure 1).

\section{Questions for consideration:}

1. Which are the most probable differential diagnoses?

2. What study would you perform next?

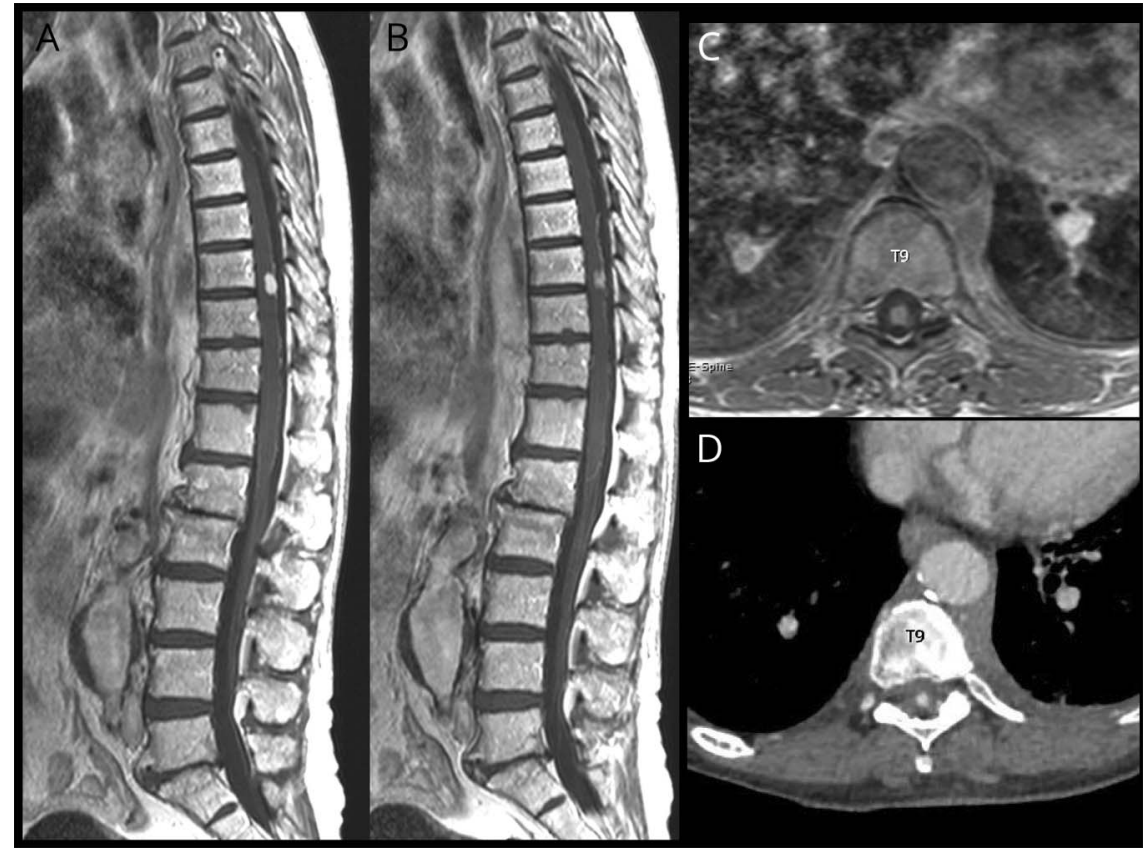

MRI sagittal (A, B) and axial (C) planes. (D) CT axial plane. The nodular lesion of the spinal cord shows important postcontrast enhancement both in MRI (A-C) and CT (D). It is associated with the engorgement of leptomeningeal vessels. An infrarenal aortic aneurysm was observed as an incidental finding. 


\section{Section 3}

The clinical findings and the MRI lesion were compatible with a transverse myelopathy. Contrast enhancement of the lesion implied a rupture of the blood-brain barrier, suggesting an inflammatory or tumoral process, and the enhancement on CT would suggest a hypervascular lesion. The most common differential diagnoses for acute and subacute transverse myelopathy include viral infections associated with enteroviruses, varicella-zoster virus, herpes simplex virus type 1 and 2, West Nile virus, HIV and cytomegalovirus, bacterial infections due to Mycoplasma pneumoniae, syphilis (generally accompanied by febrile rash syndrome, meningismus, a recent travel history, or immunosuppression), and other infectious causes of subacute evolution including fungal infections and tuberculosis. ${ }^{1}$ Noninfectious demyelinating inflammatory causes include neuromyelitis optica spectrum disorders, multiple sclerosis, spinal infarctions, and systemic inflammatory diseases such as neurosarcoidosis, Sjögren syndrome, and systemic lupus erythematosus. ${ }^{2}$ Metabolic causes associated with chronic myelopathies include vitamin $\mathrm{B}_{12}$ and copper deficiency. Other conditions include extradural, intradural, or intramedullary spinal tumors that can be subacute and are usually identifiable through MRI, although can be sometimes confused radiologically with inflammatory myelitis.

When a myelopathy develops in a progressive and insidious course for more than 3 weeks, the differential diagnosis should include intrinsic spinal cord tumors, dural arteriovenous fistula, metabolic disorders, sarcoidosis, and degenerative processes.

We decided to perform a lumbar puncture on our patient that showed a CSF with 2 cells, normal glucose $(0.5 \mathrm{~g} / \mathrm{L})$, and elevated protein $(0.9 \mathrm{~g} / \mathrm{L})$ levels. Elevated CSF total proteins is highly suggestive of a neurologic disease and indicates increased endothelial cell permeability. Some noninfectious causes (sometimes with increased cell count) include multiple sclerosis, uremia, cerebral thrombosis, polyneuritis, subarachnoid hemorrhage, CNS vasculitis, and neoplasms (in $80 \%$ of the patients with leptomeningeal metastases, the median protein concentration was between 1 and $2.4 \mathrm{~g} / \mathrm{L}$ ). Some infectious causes include purulent meningitis, tuberculous meningitis, and neurosyphilis. ${ }^{3,4}$ We received the following results: the CSF PCR for herpesvirus, varicella-zoster virus, and Epstein-Barr virus were negative. Cultures for fungi and bacteria were negative; cytology and flow cytometry were normal. Serum onconeuronal antibodies, inflammatory markers, HIV, venereal disease research laboratory, hepatitis $\mathrm{C}$, and hepatitis B and mycoplasma pneumoniae antibodies were negative. Collagen profile antibodies, vitamin $B_{12}$ level, and angiotensin-converting enzyme were also normal. There were no oligoclonal bands on CSF or sera.

We considered we were dealing with an unidentified autoimmune or neoplastic disease. A bone marrow aspiration and biopsy performed was normal; a whole-body FDG-PET scan (which was compared with a previous one) showed hypermetabolic residual tissue in the posterior mediastinum with extrapleural growth to both hemithorax and regression of the retroperitoneal hypermetabolic tissue with the exception of a lymph node in the celiac region. The patient was treated empirically with methylprednisolone $1,000 \mathrm{mg} / \mathrm{d}$ for 5 days with a slow oral tapering.

\section{Questions for consideration:}

1. Would you perform any other diagnostic study?

2. Which was the final diagnosis? 


\section{Section 4}

Two weeks after treatment, the patient's condition had worsened. A spinal cord biopsy was performed and a $5 \times$ $7 \mathrm{~mm}$ angiomatous lesion located on the posterior cord with tortuous afferent and efferent vessels was resected. The lesion was compatible with an intramedullary capillary hemangioma (figure 2).

Spinal cord tumors represent approximately $2 \%-4 \%$ of all CNS tumors and can be divided into primary or secondary. These tumors are generally classified according to their location into intramedullary, intradural, and extradural. ${ }^{5}$ MRI is the imaging modality of choice to approach the diagnosis. Selective magnetic resonance angiography may be occasionally necessary to obtain greater diagnostic certainty. Spinal cord tumors usually present in a subacute manner, or acutely when intratumoral hemorrhage occurs. On occasion, they may be confused radiologically with an inflammatory myelitis. ${ }^{6}$

Capillary hemangiomas are benign vascular lesions of the endothelium, commonly observed in the skin and soft tissues of children. Their location in the CNS is extremely rare. $^{7}$ Nowak and Widenka ${ }^{8}$ reviewed approximately 20 cases of intradural extramedullary capillary hemangiomas. Their most frequent location was at the medullary cone or the cauda equina. There are currently only 7 cases of intramedullary capillary hemangiomas reported in the literature. Pain is a common symptom of presentation usually due to dorsal root involvement. Motor symptoms are also frequent. Symptoms develop in an insidious and progressive manner in a median time of 2 years. In a case series, improvement was observed in 7 of 12 patients who underwent a surgical procedure. ${ }^{9}$ In a study following 5 patients with intramedullary hemangioma who underwent surgical treatment, a better prognosis was observed in those patients who did not exhibit residual tissue or growth on control MRI. Only 1 patient needed reintervention. ${ }^{10}$

\section{Mystery Case Responses: A 75-year- old man with an abnormal gait}

The Mystery Case series was initiated by the Neurology ${ }^{\circledR}$ Resident \& Fellow Section to develop the clinical reasoning skills of trainees. Residency programs, medical student preceptors, and individuals were invited to use this Mystery Case as an educational tool. Responses to multiple choice questions formulated using this case were solicited through a group email sent to the American Academy of Neurology Consortium of Neurology Residents and Fellows and through social media. We received 80 responses. The majority of respondents $(69 \%)$ had just been in practice for $1-4$ years; $60 \%$ were residents or fellows while $33 \%$ were faculty/board-certified physicians; the remainder were medical students or advanced practice providers. A total of $36 \%$ resided outside the United States. A wide range of practice settings was represented.

When presented with this brief vignette about a 75-year-old man with abnormal gait and his spinal MRI, $81.3 \%$ correctly identified the nodular lesion in the thoracic spine with postcontrast enhancement. Only $12.5 \%$ correctly identified the engorgement of the leptomeningeal vessels. The most frequently selected incorrect options were a nodular lesion in the thoracic spine without postcontrast enhancement (16.3\%) and retroperitoneal lesion extending into the lumbar spinal cord without postcontrast enhancement $(10 \%)$; these were not evident abnormalities.

After being given the lumbar puncture results and asked to choose the 3 most likely differential diagnoses, $80 \%$ correctly selected an intramedullary spinal neoplastic tumor. Granulomatous diseases like neurosarcoidosis (45\%) and tuberculosis spinal disease $(28.8 \%)$ were also frequently selected options. These are good differential diagnoses; however, a higher cell count in the spinal fluid would be expected. Demyelinating conditions like neuromyelitis optica spectrum disorders (5\%) and multiple sclerosis (7.5\%) were infrequently chosen. Although these conditions frequently involve

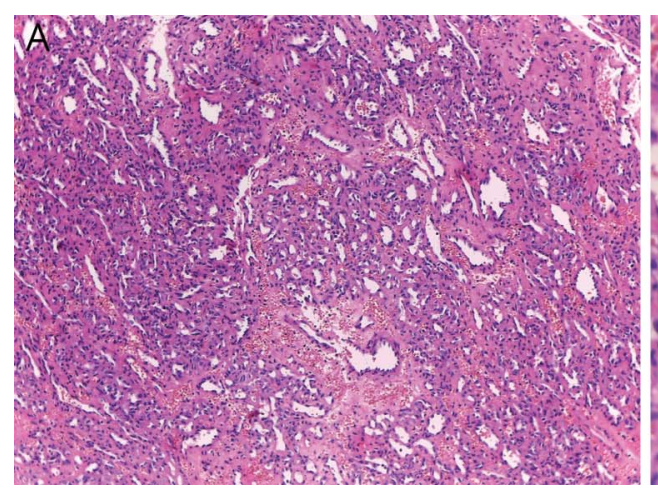

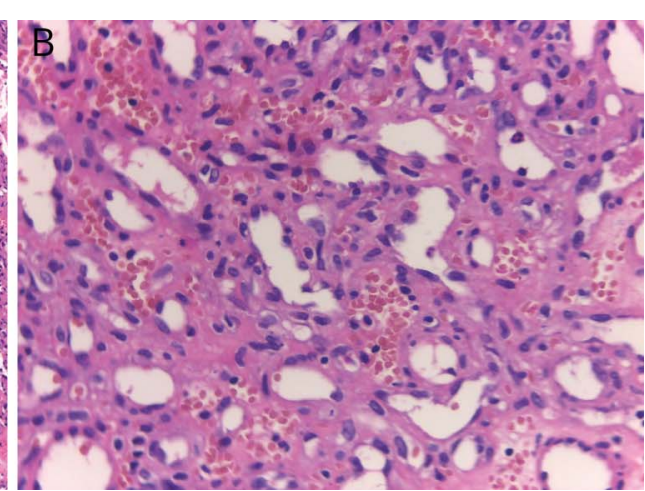

Spinal cord tissue with hematoxylin \& eosin technique. (A) Increased presence of medullar stroma (40x). (B) Red blood cells are evident inside the medullary stroma without signs of cellular atypia (100x). Compatible with capillary hemangioma. 
the spinal cord, the patient's MRI is not typical for these diseases.

Finally, the pathology was presented and participants were asked for a final diagnosis. Capillary hemangioma was correctly identified by $29.6 \%$ of participants. The next more frequent, but incorrect, choices were primary lymphoma of the spinal cord (23.5\%) and ependymoma (16\%). The figure showed closely packed cells with spaces containing blood and no cellular atypia, which is compatible with a capillary hemangioma. Hemangiomas are benign vascular malformations that can occur in any area of the body. Involvement of the spinal cord is uncommon. When involving the spinal cord, capillary hemangiomas typically occur as a vertebral lesion but rarely may be present as an intramedullary lesion. Patients with intramedullary hemangiomas are less likely to fully recover after resection compared to patients with extramedullary disease. ${ }^{1}$

Alonso Zea Vera, MD

Cincinnati Children's Hospital Medical Center

\section{Author contributions}

M. Saucedo: study concept and design, drafting of the manuscript, critical revision of the manuscript for important intellectual content. A. Chertcoff: drafting of the manuscript, critical revision of the manuscript for important intellectual content. L. Bandeo: drafting of the manuscript, critical revision of the manuscript for important intellectual content. L.L. Cejas: drafting of the manuscript, critical revision of the manuscript for important intellectual content. C.U. Roca: drafting of the manuscript, critical revision of the manuscript for important intellectual content. P. Bonardo: drafting of the manuscript, critical revision of the manuscript for important intellectual content. M.F. Pardal: drafting of the manuscript, critical revision of the manuscript for important intellectual content. R. Torino: drafting of the manuscript, critical revision of the manuscript for important intellectual content. J. Mendez: drafting of the manuscript, critical revision of the manuscript for important intellectual content. R. Reisin: drafting of the manuscript, critical revision of the manuscript for important intellectual content.

\section{Study funding}

No targeted funding reported.

\section{Disclosure}

The authors report no disclosures relevant to the manuscript. Go to Neurology.org/N for full disclosures.

\section{References}

1. Schmalstieg WF, Weinshenker BG. Approach to acute or subacute myelopathy. Neurology 2010;75:S2-S8.

2. Debette S, de Sèze J, Pruvo JP, et al. Long-term outcome of acute and subacute myelopathies. J Neurol 2009;256:980-988.

3. Eeg-Olofsson O, Link $\mathrm{H}$, Wigertz A. Concentrations of CSF proteins as a measure of blood brain barrier function and synthesis of IgG within the CNS in normal subjects from the age of 6 months to 30 years. Acta Paediatr Scand 1981;70:167-170.

4. Andersson M, Alvarez-Cermeño J, Bernardi G, et al. Cerebrospinal fluid in the diagnosis of multiple sclerosis: a consensus report. J Neurol Neurosurg Psychiatry 1994; 57:897-902.

5. Duong LM, McCarthy BJ, McLendon RE, et al. Descriptive epidemiology of malignant and nonmalignant primary spinal cord, spinal meninges, and cauda equina tumors. Cancer 2012;118:4220-4227.

6. Shin JH, Lee HK, Jeon SR, Park SH. Spinal intradural capillary hemangioma: MR findings. AJNR Am J Neuroradiol 2000;21:954-956.

7. Hem S, Landriel F, Hasdeu S, Kitroser M, Peña L, Vecchi E. Hemangioma capilar medular: reporte de un caso y revisión de la literatura. Rev Argent Neurocir 2008;22.

8. Nowak D, Widenka D. Spinal intradural capillary hemangioma: a review. Eur Spine J 2001;10: 464-472.

9. Kasukurthi R, Ray WZ, Blackburn SL, Lusis EA, Santiago P. Intramedullary capillary hemangioma of the thoracic spine: case report and review of the literature. Rare Tumors 2009; 1:e10.

10. Wu L, Deng X, Yang C, Xu Y. Intramedullary spinal capillary hemangiomas: clinical features and surgical outcomes: clinical article. J Neurosurg Spine 2013;19: $477-484$.

\section{Reference}

1. Babu R, Owens TR, Karikari IO, et al. Spinal cavernous and capillary hemangiomas in adults. Spine 2013;38:E423-E430.

\section{Committed to Making a Difference: 2020 American Academy of Neurology Research Program}

The American Academy of Neurology (AAN) is committed to making a profound difference in the lives of researchers, in turn making a difference in the lives of patients with brain disease. The ambitious 2020 AAN Research Program offers opportunities ranging from $\$ 130,000$ to $\$ 450,000$ and designed for all types of research across all career levels and discovery stages. Pave your own pathway to patient care by applying for one of the opportunities by the October 1, 2019, deadline.

Visit AAN.com/view/ResearchProgram today. 


\section{Neurology}

Mystery Case: A 78-year-old man with a gait disorder

Miguel Saucedo, Anibal Chertcoff, Lucrecia Bandeo, et al.

Neurology 2019;93;223-227

DOI 10.1212/WNL.0000000000007865

This information is current as of July 29, 2019

\section{Updated Information \& Services}

\section{References}

Subspecialty Collections

Permissions \& Licensing

Reprints including high resolution figures, can be found at: http://n.neurology.org/content/93/5/223.full

This article cites 10 articles, 3 of which you can access for free at: http://n.neurology.org/content/93/5/223.full\#ref-list-1

This article, along with others on similar topics, appears in the following collection(s):

All Clinical Neurology

http://n.neurology.org/cgi/collection/all_clinical_neurology

All Education

http://n.neurology.org/cgi/collection/all_education

All Spinal Cord

http://n.neurology.org/cgi/collection/all_spinal_cord

Gait disorders/ataxia

http://n.neurology.org/cgi/collection/gait_disorders_ataxia

Spinal cord tumor

http://n.neurology.org/cgi/collection/spinal_cord_tumor

Information about reproducing this article in parts (figures,tables) or in its entirety can be found online at:

http://www.neurology.org/about/about_the_journal\#permissions

Information about ordering reprints can be found online:

http://n.neurology.org/subscribers/advertise

Neurology ${ }^{\circledR}$ is the official journal of the American Academy of Neurology. Published continuously since 1951, it is now a weekly with 48 issues per year. Copyright (O 2019 American Academy of Neurology. All rights reserved. Print ISSN: 0028-3878. Online ISSN: 1526-632X.

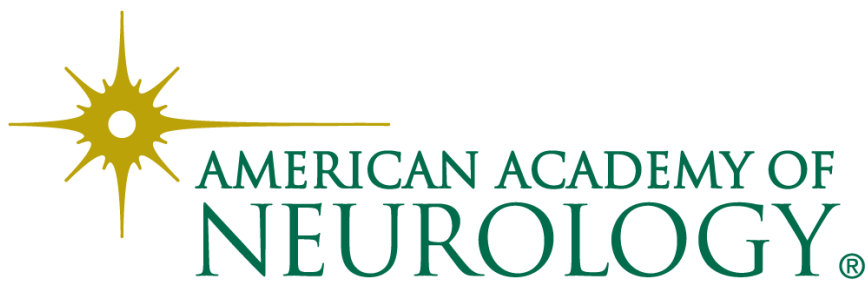

